\title{
Veiledning i lærerstudenters praksisopplæring - et bidrag til læring og utvikling?
}

\author{
Geir Luthen ${ }^{1 *}$, Olav Kolstad ${ }^{1 *}$ \\ ${ }^{1}$ Høgskolen i $\emptyset$ stfold
}

\section{Sammendrag}

Denne studien er gjennomført på bakgrunn av et målrettet samarbeid mellom to videregående skoler og en lærerutdanningsinstitusjon med en målsetting om å styrke og utvikle en bedre sammenheng mellom praksisopplæring, pedagogikk og didaktikk. I teksten retter vi oppmerksomheten mot veiledning som et framtredende element i samarbeidet mellom de tre institusjonene. Vi st $\varnothing$ tter oss hovedsakelig til sentral teori om veiledning (Lauvås \& Handal, 2014), teori som dreier om utvikling av det tredje rom (Zeichner, 2010) og om koherens i lærerutdanning (Raaen, 2014). Det metodologiske grep er deltakende aksjonsforskning, og datainnsamlingsmetoden som er tatt i bruk benevnes som brevmetoden (Berg, 2003). I artikkelen viser vi til og drøfter funn som tyder på at ganske ulike tilnærminger til måter å veilede på, kan bidra til læring og utvikling, og at praksislærers veiledningsfaglige kompetanse er avgjørende for kvaliteten på veilednings $\varnothing$ ktene. Videre tyder funnene på at lærerstudenter ikke setter pris på monologisk og kontrollfiksert veiledning. Funnene avdekker også at praksislærere ser det som en naturlig del av sitt ansvar å veilede studenter inn i lærerprofesjonen. Både studenter og praksislærere gir uttrykk for at de opplever trepartsamtalen som særdeles verdifull og læringsfremmende, samtidig som tid og ressurser i veiledningen oppleves som kritiske suksessfaktorer.

This study has been carried out based on a targeted collaboration between two upper secondary schools and a teacher education institution. The goal is to develop a more coherent teacher education. In this article we focus on mentoring, because we consider it to be a crucial factor for making the collaborative quality between the three institutions better, as well as increasing the students' learning outcomes of their practicums. We rely mainly on central theory about mentoring (Lauvås \& Handal, 2014), theory concerning the development of 'the third space' (Zeichner, 2010) and coherence in teacher education (Raaen, 2014). The methodological approach is participatory action research, and the letter method is used to collect data (Berg, 2003). Findings show that rather different mentoring approaches can contribute to learning and development, and that the quality of the mentoring sessions depends highly on the mentors' competence. Furthermore, we find that students do not appreciate monologue and control-oriented mentoring. The findings also show that the school mentors consider guiding the students into the teacher profession as an obvious part their work-obligation. Both students and mentors agree upon that the three angled conversation between the student, the practicum teacher and the mentor from the teacher training institution is particularly valuable and learningpromoting, while enough time and resources are considered to be crucial for success.

Fagfellevurdert artikkel. Publisert: 20.12.2018 
Nøkkelord: Veiledning; koherens i utdanningen; det tredje rom; aksjonsforskning; trepartsamtalen

* Kontakt:

Geir Luthen

Avdeling for lærerutdanning

Høgskolen i Østfold

E-post: geir.s.luthen@hiof.no
Olav Kolstad

Avdeling for lærerutdanning

Høgskolen i Østfold

E-post: olav.e.kolstad@hiof.no

\section{Bakgrunn}

Hensikten med denne studien er å unders $\varnothing$ ke mulighetene for å utvikle et bedre samarbeid mellom praksisskoler og lærerutdanningen ved praktisk pedagogisk utdanning (PPU) på en høgskole. PPUutdanningen er av stor betydning for å dekke behovet for godt utdannede lærere på trinn 8 - 13 i den norske skolen (Kunnskapsdepartementet, 2008). Artikkelforfatterne arbeider med lærerutdanning ved PPU og følger lærerstudentene gjennom hele deres studium. Vårt faglige ståsted er i pedagogikkfaget. I tillegg er det en sentral oppgave å veilede studenter og praksislærere gjennom 11 uker i praksisopplæring, samt å koordinere PPU-studiets tre komponenter: praksisopplæring, pedagogikk og fagdidaktikk. Vi følger studentene i den daglige og uformelle kommunikasjon og i form av regelmessige, summative evalueringer av PPU-studiet. Våre tidligere erfaringer samsvarer med nasjonale evalueringer, som konkluderer med at PPU ikke forbereder studentene i tilstrekkelig grad til utførelsen av læreryrket (Lid, 2013). Mange grep er tatt de senere årene for at PPU-utdanningen skal ta mer hensyn til selve praksisfeltet, hvor lærer møter elev. Raaen (2014) dokumenterer at det er stor avstand mellom det som foregår på campus, og det som foregår i klasserommet. Vi inviterte to videregående skoler i 2014 til et partnerskap med den hensikt å utvikle et samarbeid om hvordan praksisfeltet og lærerutdanningen kunne arbeide sammen om og med studentene for å skape en mer integrert og relevant lærerutdanning. Studentene underviste på alle tre trinn i videregående skole, i de fleste fag og på ulike utdanningsprogram. I perioden fra august 2014 til april 2016 har vi tilrettelagt for ulike tiltak:

- Studentene er på samme skole i to relativt lange praksisperioder, en periode på fem uker om høsten, og en periode på seks uker på våren

- Lærerutdannere har avsatt tid i sine arbeidsplaner til å utvikle samarbeidet med praksisskolene

- Lærerutdannere observerer studentenes undervisning og er med i trepartssamarbeidet

- Lærerutdannere underviser praksislærere og studenter på praksisskolene, i tema som veiledning, profesjonsetikk og studentevaluering

- Praksislærere og skoleledere fra praksisskolene underviser studenter og lærerutdannere på campus

- Praksislærere tilbys formell veilederutdanning på høgskolen

- Det foretas systematiske evalueringer sammen med praksisskolene og studenter etter hver praksisperiode

\section{Studiets design og forskningsspørsmål}

Overnevnte tiltak, inklusive mangfoldet og kompleksiteten som oppstår når lærerstudenter, praksislærere og høyskoleansatte møtes, kan relateres til interessante forskningstema som er viet mye plass i forskning på høyere utdanning (Halvorsen, 2014; Chambers og Armour, 2012; Le Cornu, 2010). I vår studie har vi valgt en fenomenologisk tilnærming til vårt datamateriale som består av utsagn fra studenter og praksislærere i brevs form, se mer om dette under kapittel om Metodologi. I brevene fra informantene blir veiledning tillagt stor betydning i praksisopplæringen. I et nært samarbeid mellom praksisskoler og læringsutdanningsinstitusjon om studentenes praksis hadde vi også en forforståelse av veiledning som et sentralt element. Veiledning var altså både et vektlagt tema i informantenes tekster og i vår oppfatning av fenomenets betydning for kvaliteten på studenters praksisopplæring. Dette fokussammenfallet gjorde 
at vi valgte følgende forskningsspørsmål: Hvilke bidrag kan veiledning gi i lærerstudenters praksisperioder?

\section{Teoretisk rammeverk}

I denne delen av teksten presenteres vår forståelse av veiledningsbegrepet, samtidig som vi forsøker å vise at aktørene i vår studie over tid har utviklet en utvidet og kontekstuell forståelse av begrepet veiledning. Videre tar vi for oss begrepene det tredje rom og koherens og gir disse et meningsinnhold tilpasset vårt formål. Vi oppfatter det tredje rom og koherens som sentrale for å kunne forstå og utvikle forholdet mellom praksisfelt og lærerutdanningsinstitusjon. Etter hvert knytter vi de tre begrepene det tredje rom, koherens og veiledning sammen, og viser hvordan en samlet forståelse og operasjonalisering av disse kan bidra til kollektiv læring på tvers av systemer.

\section{Veiledningsbegrepet og veiledningstilnærminger}

Vår forståelse av veiledning ligger tett opp til veiledningsbegrepet slik det er presentert i handlings- og refleksjonsmodellen (Lauvås \& Handal, 2014). Denne tilnærmingen legger vekt på en god relasjon mellom veisøker og veileder, at veisøker motiveres til refleksjon og åpenhet for ulike forståelser av hva som kjennetegner lærerprofesjonen. I internasjonal litteratur samsvarer developemental mentoring langt på vei med handlings- og refleksjonsmodellen. I en doktoravhandling om veiledning, benevner Lejonberg denne formen for veiledning for utviklende veiledning (Lejonberg, 2016). Handlings- og refleksjonsmodellen utgjør mye av den ideologiske og teoretiske grunnstammen i høgskolens veilederutdanning. I en innledende fase i forskningsprosjektet ble handlings- og refleksjonsmodellen pekt på som en gyldig og anbefalt tilnærming til å utvikle veilederkompetanse. Med handling- og refleksjonsmodellen som veiledningsfaglig ståsted presenterte vi som lærerutdannere og forskere teoretisk begrep som praktisk yrkesteori, veiledningssløyfa og refleksjon i felles læringsøkter med praksislærere og studenter. Praktisk yrkesteori beskrives som en personlig, tankemessig beredskap med elementer fra egen erfaring, ispedd informasjon om andres erfaringer, satt inn i en ramme av teoretisk innsikt og ordnet etter verdier som veisøker oppfatter som viktige (Lauvås \& Handal, 2014).

En annen form for veiledning er det som Lejonberg kaller klar veiledning. Den kjennetegnes av at «veileder formidler konkrete råd, klare tilbakemeldinger, samt kommuniserer egne vurderinger av veisøkers praksis» (Lejonberg, 2016, s. 5). Noen praksislærere utøver en veiledningsform som går under betegnelsen supervisjonstradisjonen (Gordan, 1992). Den har mange likhetstrekk med klar veiledning.

Clarke m.fl. (2013) har gjort en metastudie avveiledningsforskning på lærerstudenter i praksisopplæring. Studien avdekker bl.a. to ganske ulike veileder-roller som korrelerer med de to overnevnte veiledningsmodeller. Den ene rollen var «maestro» hvor praksislæreren som ekspert ga klar retning til hvordan studentene skulle opptre, korrelerer i stor grad med klar veiledning. Den andre rollen var «mentor-rollen». Den preges av at praksislæreren gir rom for utprøving, og er åpen for innspill og undring. Denne rolleutøvingen er nært knyttet til handlings- og refleksjonsmodellen og utviklende veiledning.

Nilssen (2007) peker på en overgripende veilederrolle som tar opp i seg elementer fra både utviklende veiledning og klar veiledning. Den innebærer at praksislærer veileder lærerstudentene både direkte og indirekte. Praksislæreren viser da sine studenter hvordan hun underviser, og samtidig legger til rette for drøfting og refleksjon av felles opplevelser. Denne måten å veilede på bygger på antakelsen om at det $\mathrm{i}$ praksisfeltet eksisterer flytende overganger mellom de ulike veiledningsformene.

Gjennom prosessorientert dialog med oss som lærerutdannere og forskere har praksislærere og studenter etter hvert blitt presentert for og utviklet en forståelse for at det foreligger et mangfold av ulike tilnærminger til å veilede studenter, og at kompetente veiledere utvikler flere måter å veilede på som er tilpasset konteksten. Denne utvidede og kontekstuelle forståelsen bekreftes også av ny forskning på veiledningsfeltet (Lejonberg, 2016). Over tid har altså oppmerksomheten blitt flyttet fra et noe ensidig fokus på handlings- og refleksjonsmodellen til å variere bruken av modeller med tilhørende strategier og 
redskaper i samsvar med situasjonens fordringer. Man kan tale om aktør- og situasjonstilpasset veiledningspraksis.

\section{Det tredje rom}

McDonald et al. (2013) anbefaler at istedenfor først å utvikle og implementere et programdesign for partnerskap mellom skole og lærerutdanning bør designet utvikle seg i et «undersøkende felleskap», som kan dokumentere og forklare handlinger og mangefasetterte interaksjoner. Zeichner (2014) har stått sentralt i forskningsarbeidet med å utvikle forståelsen av begrepet det tredje rom som felleskap og møtested. Det tredje rom beskriver samhandlingsprosesser knyttet til lærerutdanning. Begrepet kan nyttiggjøres til å synliggjøre mulighetene som ligger i et nært samarbeid mellom løst knyttede deler i profesjonsutdanning. Partene går ut av sine respektive kunnskapsfelt og inn i et nytt som de skaper sammen. Ideen om det tredje rom er ment som en mulighet for å skape en arena for å koble sammen praktisk og akademisk kunnskap. Ofte framstilles forholdet mellom teori og praksis, representert henholdsvis ved høgskole og praksisskole, som motsetningsfylt. Zeichner (2010) mener at det slett ikke behøver å være slik. I stedet kan det bli en samhandlingsarena hvor det kan skje en integrering av spørsmål og perspektiver som ofte blir sett på som konkurrerende diskurser. Et enten/eller-perspektiv forvandles til et både/og-perspektiv (Zeichner, 2010). Konkret innebærer dette at praksislærerne på skolene får informasjon om hva studentene faktisk studerer på campus, og at lærerutdannerne setter seg bedre inn i hva det vil si å være lærer i praksisfeltet. Lærerstudentene på sin side, vil da få en opplevelse at praksislærere og lærerutdannere kjenner til hverandres egenart, at oppgaver og roller er avklart, og at de på den måten lettere kan samarbeide.

Helleve og Langøren kobler det tredje rom opp mot veiledning ved å se veilederutdanning som et rom som lærerutdannere og lærere bygger sammen. De hevder at «veilederen og veilederutdanningen danner broen mellom institusjonene gjennom å gi st $\varnothing$ tte til profesjonell utvikling for alle parter i organisasjonene» (Helleve \& Langøren, 2018, s. 190). Lærerutdanningen skaffer seg økt kunnskap gjennom å synliggjøre veilederstudenters erfaringer, og veilederne får tilgang til ny teori gjennom lærings $\varnothing$ kter som legger vekt på sentral, aktuell forskning. Et antall praksisveiledere ved våre praksisskoler har tatt omtalte veilederutdanning eller er i ferd med å gjennomføre denne utdanningen.

\section{Koherens}

Beslektet med tenkningen om det tredje rom er begrepet koherens, når dette brukes for å forstå og drøfte sammenheng og relevans i lærerutdanningen. Koherens handler bl.a. om grader av sammenheng $\mathrm{i}$ utdanningen (Raaen, 2014; Darling-Hammond, 2014; Hammernes, 2006). Koherens har blitt et viktig begrep med hensyn til å forklare og forstå kvalifisering til yrker og profesjoner, deriblant relevans og faglig nivå i lærerutdanningene. Raaen (2014) har gitt viktige innspill til å utvikle koherensbegrepet slik at det også kan hjelpe oss til å gripe kompleksiteten i en profesjonsutdanning som lærerutdanningen faktisk er. Slik begrepet oppfattes og brukes i norsk utdanningskontekst, betyr det grad av sammenheng både mellom fagene i utdanningene og mellom utdanning og praksisfelt (Heggen, 2010). I sine studier av begrepet coherence i amerikansk utdanningskontekst legger Darling-Hammond (2014) og Hammerness (2006) vekt på det sistnevnte forhold; forholdet mellom lærerutdanning og praksis-skoler. I vår sammenheng er det nettopp forholdet mellom vår egen lærerutdanning og våre praksisskoler vi har rettet vår oppmerksomhet mot.

Koherens blir gitt noe ulikt innhold avhengig av hvem som utforsker og bruker begrepet $\mathrm{i}$ utdanningssammenheng. Tatto (1996) vektlegger en felles forståelse om det å nå det felles mål om å kvalifisere profesjonelle lærere som effektivt kan undervise elever. Grimen (2008) er opptatt av at det faglige innholdet i utdanningen må peke på de praktiske oppgavene som skal utføres i yrket. Raaen (2014) påpeker at begrepet også må omfatte syntetisering av ulike læreprosjekt lærerstudenten er inne i, altså om studenten selv opplever sammenheng i sin læringsprosess. Med utgangspunkt i kompleksiteten i lærerutdanningen argumenterer han for nødvendigheten av at koherens i tillegg tar for seg kollektiv kunnskapsutvikling og kunnskapsutvikling i nettverk. 
Læring i lærerutdanning oppstår i interaksjon mellom studenter, praksislærere (og elever) og lærerutdannere, og i samspillet mellom systemene høgskole og praksisskole. Når aktørene samhandler, skapes tanker og læring som blir en felles referanseramme som er mer omfattende enn det den enkelte deltaker selv kan utvikle. Dette kan bidra til at den individuelle læringen utvides til å bli en sammenhengende kollektiv læringsprosess (Tuomi-Gröhn, 2007). Raaen er opptatt av at koherens i lærerutdanning må inkludere "samspill på tvers av system» (Raaen, 2014). Han viser til en praksis der lærerutdannere, praksisskoler og studenter er organisert slik at de deler sine konkrete erfaringer knyttet til de samme fenomen og spørsmål om undervisning. Slik kan det skapes en plattform for felles utvikling av reflekterte handlinger.

I følge Schollaert (2011) kan komplementær kompetanse hos partene i et samarbeid gi arbeidet i dette nettverket en synergieffekt i form av ny og felles kunnskap. Synergieffekten betinges av at partene tar inn over seg at det er en styrke at kunnskap og ferdighet er ulik og ulikt fordelt. I en slik forståelse vil koherens ikke være en «monolittisk oppfatning og en korresponderende praksis, men som en rik variasjon av temaet» (Schollaert, 2011).

Darling-Hammond (2014) ser coherence som særdeles kraftfullt til å fremme og skape en sømløs opplevelse av «learning to teach». Hun knytter også coherence til veiledning når hun hevder at hyppig veiledning av høy kvalitet (supervision) bidrar til en opplevelse av sammenheng mellom teori og praksis. «... The importance of extensive and intensely supervised clinical work - tightly integrated with coursework - allows candidates to learn from expert practice in schools...» (Darling-Hammond, 2014, s. 550) og videre: «In addition, the quality and intensity of supervision, are factors that may be potensially important elements of teacher learning» (Darling-Hammond, 2014, s. 551). Hammerness, DarlingHammond, Shulman (2002) har fordypet seg i og har gitt bidrag til forståelse og videreutvikling av begrepet coherence, ved å betrakte coherence som en stadig pågående prosess for læring og utvikling mer enn et mål som kan nås. Hammerness (2006, s. 1263) sier det slik: «Rather, efforts towards coherence should be understood as part of the steady work of such programs, a continuing and necessary effort of adjustment, revision, and calibration ». I vår sammenheng er det spesielt interessant at også hun kobler veiledning opp mot coherence, og poengterer at veiledning kan bidra til større grad av coherence. Imidlertid knytter hun noen betingelser til omfanget og kvaliteten på veiledningen for at dette skal kunne bidra til økt coherence. I følge Hammerness (2006) bør veiledning av studenter preges av at veilederen har et bevisst forhold til valg av veilednings-strategi og -modell. Dette kan forstås i retning av at veilederen har tilegnet seg formell veilederkompetanse som gjør at hun har utviklet en måte å veilede på som er tilpasset den konteksten veiledningen foregår i. Hun viser også til praksiser på partnerskoler som legger til rette for at veilederne møtes til kollektive læringsøkter for å drøfte og dele utfordringer knyttet til det å være veileder (Hammerness, 2006). På våre praksisskoler møtes studenter, praksislærere og representant fra høyskolen i for- og etterkant av hver praksisperiode til felles læringsøkter der forhold knyttet til veiledning har en sentral plass.

\section{Metodologi}

\section{Forskningsstrategien og dens utfordringer}

Vår forskningsstrategi i denne studien benevnes som deltakende aksjonsforskning (Pålshaugen, 1994). Strategien tilsier at forskerne og deltakerne over tid følger en prosess, at oppmerksomheten rettes mot både prosess og utbytte, og at den forståelsen, som ligger til grunn for strategien, vektlegger deltakelse, handling og refleksjon. Det formative aspekt er sterkt vektlagt. Aspektet muliggjør læring og utvikling gjennom dialog mellom deltakere og forskere, hvor de førstnevnte oppfatter seg selv som aktive agenter for forandring på egne arbeidsplasser. «Følgebegrepet tilsier at hensikten er å følge opp noe, i betydningen at forskeren følger en prosess over tid med fokus på prosessen og løpende resultater, og er dermed knyttet til en empirisk kontekst.» (Segaard, 2007, s. 8). Forskere, praksislærere, skolens ledelse og studenter hadde ulike posisjoner i vårt forskningsprosjekt. Vi som lærerutdannere forsket på 
praksislærere og studenter, mens praksislærerne og delvis skolens ledelse bidro til å gi førende retning til tempo og utvikling av prosjektet. Studentene påvirket også i noen grad prosjektets utvikling gjennom samtaler, logger og brev.

Utfordringene knyttet til oss som forskere i en samhandlende rolle med ledelse og praksislærere på våre praksisskoler kan være flere. Vi risikerer å bli utsatt for et press for at vi i sterkere grad skal medvirke til å gi et utviklingsforløp en tydeligere retning. Eller vi kan selv stå i fare for å agere mer intervenerende for å teste ut teori eller modeller som vi ønsker å forske på. Vi oppfatter selv at vi i vår forskning og samhandling med våre praksisskoler ikke har grepet direkte og intervenerende inn i de prosesser vi har $\emptyset n s k e t$ å unders $\varnothing$ ke, og at vi slik sett ikke har vært inhabile. Vi har forholdt oss til de vitenskapelig og etiske prinsipper som gjelder for god forskning, dette til tross for vårt nære forhold til praksisskoler, praksislærere og studenter. Samtidig ser vi at vår forskning vanskelig kan betraktes som verdifri. Det er vi som forskere som har valgt forskningsspørsmål, teoretisk vinkling og metodologisk strategi. I sin drøfting og kritikk av Webers verdifrihetslære (1956), peker Tranøy (1986) på at forskeren ikke er verdinøytral og ansvarsfri. Som forskere har vi en forforståelse av de fenomener vi ønsker å unders øke. Denne forforståelsen ligger nær opp til det Lauvås og Handal kaller «praktisk yrkesteori»: «... det finnes en slik privat, tankemessig beredskap med elementer fra egen erfaring, ispedd informasjon om andres erfaringer, satt inn i en ramme av teoretisk kunnskap og innsikt og ordnet etter verdier vi oppfatter som viktige» (Lauvås \& Handal, 2014, s. 28).

\section{Etiske utfordringer}

Vår forskning er praksisnær, det vil blant annet si at den kunnskap og kompetanse som utvikles gjennom forskningen, skal nyttiggjøres i den praksis vi forsker på. Nærheten skaper utfordringer knyttet til å beholde vårt "forskerblikk» samtidig som vi erkjenner nærhetens innvirkning på relasjoner mellom aktørene. Blant de etiske utfordringer som vi opplevde at vår forskning stilte oss overfor, var forhold koblet til nytte, samtykke og gjensidighet. I forkant av forskningsprosjektet hadde vi samtaler med praksisskolenes ledelse, praksislærere og lærerstudenter om hvor nyttig vår forskning var for dem og praksisfeltet. Vi la vekt på at samtlige deltakere og berørte parter skulle oppleve temaet som relevant, dels fordi dette ville kunne bidra til læring, og dels fordi de rent praktisk måtte investere energi og tid til deltakelse i prosjektet. Samtlige deltakere ga utrykk for at de opplevde prosjektet som relevant, bl.a. fordi de ble holdt informert om resultater og våre tolkninger av resultatene. Etter hvert som forskningen stadig mer rettet oppmerksomheten mot veiledning, gjennomførte vi samtaler med de berørte om prosesssamtykke, hvilket vil si dialog som innebærer at deltakerne samtykker i endret eller økt fokus i forskningsprosessen (Munhall, 2007). Dialogen med deltakerne var preget av gjensidighet hvor vi som forskere søkte å kommunisere med deltakerne som likemenn. Fangen (2009) framstiller gjensidighet som en prosess der forskerne legger fram forskningsopplegg, resultater og tolkninger på en åpen måte, med mulighet til at deltakerne kan gi korrigerende tilbakemeldinger før publisering. En slik forståelse av gjensidighet er beslektet med tenkningen om det tredje rom (Zeichner, 2010). I forkant av prosjektet hadde vi innhentet informert samtykke, noe som innebar at informantene frivillig samtykket i deltakelse under den forutsetning av at de hadde forstått hva forskningen omhandlet. En annen forutsetning var at materialet ble anonymisert og ikke kunne spores tilbake til enkeltpersoner.

\section{Datainnsamling og brevmetoden}

Vi valgte brev-metoden som verkt $\varnothing$ y i datainnsamlingen (Berg, 2006). Brevmetoden innebar at vi ba våre informanter skrive brev til oss som forskere, om det å være henholdsvis praksislærere og lærerstudenter i praksis. Vi ønsket at brevene skulle være ganske detaljerte og av en viss lengde. Ut over det stilte vi ingen krav til innhold. Et fortrinn ved denne datainnsamlingsmetoden er at vi som forskere kan få tilgang til vesentlig informasjon som vi trolig ikke ville ha fått hvis vi for eksempel hadde intervjuet informantene. Dersom informantene unnlater å skrive noe som vi forskere gjerne skulle ønsket å få kjennskap til, kan imidlertid brevmetoden oppleves begrensende. Brevmetoden kan også stimulere aktørenes læring da de ved å skrive ned sine tanker og betraktninger, utvikler kunnskap og dypere forståelse av de tema de tar 
opp i brevene (Dysthe, 1995). Fra forskerhold er det reist innvendinger mot å betrakte brevmetoden som en pålitelig datainnsamlingsmetode, bl.a. fordi metoden tar utgangspunkt i det personlige narrative (Walford, 2004). Ellis og Bochner ser på brevmetoden som en narrativ framstilling som «... is always a story about the past and not the past itself» (Ellis \& Bochner, 2000, s. 411). Vi oppfatter at vi langt på vei har kompensert for det introspektive og individualiserte perspektiv i brevene ved at vi har lest mange brev om de samme fenomen og på den måten har vi generert et samlet bilde av vårt materiale. Datamaterialet består av 19 brev fra praksislærere på de to praksisskolene, og 21 brev fra lærerstudenter som har vært i to praksisperioder på disse skolene. Brevene er skrevet i perioden fra november 2014 til februar 2016.

\section{Dataanalysen}

Brevmetoden er inspirert av en fenomenologisk tilnærming og analyse av innholdet i brevene vi mottok fra deltakerne (Giorgi, 1997). Deres frie tekster om «å være lærerstudent i praksis» og om «å være veileder for lærerstudenter», ble derved det fenomen vi ønsket å generere kunnskap om. Det første trinn var å motta og samle brevene fra våre informanter. Det andre trinn i prosessen var å lese gjennom alle brevene for å utvikle et helhetlig bilde av det innsamlede materiale, og for å danne oss et inntrykk av hvordan de deler av materialet som skal være utgangspunkt for analyse, sto i forhold til hverandre. I det tredje trinn delte vi materialet inn i kategorier eller meningsenheter som kunne knyttes til hensikten med vårt forskningsarbeid, dette kaller Giorgi «constituting parts known as meaning units» (Giorgi, 1997, s. 239). Dette innebar også at deler av materialet ble definert som ikke essensielle bidrag med hensyn til å gi informasjon om tema og forskningsspørsmål. De hovedkategoriene vi avdekket i denne fasen dreide seg om undervisning, om det å være student/medstudent, om elever, om lærerutdanningsinstitusjonen, om praksisskolen, om forventninger til praksisopplæringen og om veiledning. Til slutt samlet og oppsummerte vi våre funn som et grunnlag for kunnskapsutvikling i fagfellesskapet. I denne avsluttende fasen valgte vi å Iøfte fram hovedkategorien veiledning som grunnlag for kunnskapsutvikling gjennom vårt drøftingskapittel, dels fordi vi her fant det mest omfattende materiale, og dels fordi funnene i sterk grad ga oss nyttig og interessant informasjon til vårt videre samarbeid med praksisfeltet.

\section{Funn og drøfting}

Brevene fra studenter og praksislærere utgjør et omfattende datamateriale. Det beskriver mange sider ved samarbeidsprosessene som foregår mellom aktørene, knyttet til henholdsvis praksisskoler og lærerutdanningsinstitusjon. I denne artikkelen omtales beskrivelser rubrisert under hovedkategorien veiledning. Informantene omtaler ulike forhold knyttet til veiledning, bl.a. relasjoner, veiledningssamtalers innhold og form, refleksjon, praksislærernes veilederkompetanse, praksislærere som rollemodeller, og veiledningen som verdivalg. Studenters og praksislæreres ytringer er i noen grad samstemte, og de utrykker relativt like oppfatninger av de overnevnte forhold. Om andre veiledningsforhold spriker uttalelsene mer. På noen områder hevdes det til dels motstridende oppfatninger. I noen grad er de opptatt av det å inngå i utforskende relasjoner. Det innebærer bl.a. at praksislærerne diskuterer oppfatninger av didaktikk og pedagogikk med sine studenter, eller det motsatte at studenter opplever å ha en hierarkisk og monologisk distanse til sine praksislærere (Zeichner, 2010). I denne artikkelen ser vi nærmere på følgende deltemaer i veiledning: Ulike veiledningsforståelser og tilnærminger, praksislærerens mangelfulle veiledningskompetanse og tilretteleggingssvikt, felles læring i det tredje rom, koherensillojalitet $\mathrm{i}$ veiledningen, verdivalg, trepartsamtalen og tid og ressurser $\mathrm{i}$ veiledningen. Avslutningsvis tar vi for oss studentenes forhold til medstudenter og til oss lærerutdannere, uten at det drøftes inngående.

\section{Ulike veiledningsforståelser og tilnærminger}

Studentene har med seg ulike erfaringer og ulik kompetanse i møtet med praksisopplæring og praksislærere. De har forskjellige fag, med ulik fordypning i fagene. Noen har arbeidet som lærere, og andre er noviser. Praksislærerne er også ulike med hensyn til kompetanse, fagbakgrunn, erfaring og 
utdanning. Dette mangfoldet bidrar til at studentene blir veiledet ulikt; noen rådgivende og direkte, andre mer i form av åpne spørsmål. En praksislærer ytrer seg slik: «Er mine erfaringer svar på spørsmålene om hvordan studenten vil være som lærer? Jeg vil ikke skape kopier av meg selv, men vil få studenten til å tenke selv». En annen praksislærer betrakter veilederroller annerledes: «Jeg har lært at jeg må være mye mer tydelig på hva som forventes av studentene». De to sitatene vitner om to ganske ulike tilnærminger til veiledning av lærerstudenter. Det første sitatet tyder på en tilnærming preget av handlings- og refleksjonsmodellen som legger til grunn en åpen, undersøkende, kritisk og begrunnelsesorientert form for veiledning (Lauvås \& Handal, 2014). Handlings- og refleksjonsmodellen har som utgangspunkt at veisøker, i vår sammenheng studenten, med støtte fra praksislærer, selv langt på vei er i stand til å finne svar på de profesjonelle utfordringer han står overfor. Praksislærer blir på denne måten en slags fødselshjelper som legger til rette for at veisøker kan utvikle sin egen, personlig preget, praktiske yrkesteori.

Det andre sitatet, om tydelighet, kan i sterkere grad knyttes til en veiledningstilnærming tilhører supervisjonstradisjonen. Supervisjon kjennetegnes bl.a. ved at veiledningen foregår over et lengre tidsrom, at den foregår mellom en kompetent og en ikke-kompetent, at supervisor har ansvar for det den som er under opplæring foretar seg, og at fokuset er på yrkesfaglige forhold (Gordan, 1992). Et studentutsagn illustrerer en veiledningstilnærming preget av et ulikevektet forhold mellom den kompetente og den mindre kompetente: «Jeg fikk tilbakemelding på at jeg vurderte elevene ganske likt praksislæreren, og det var betryggende». Praksislæreren fungerer i denne situasjonen som rollemodell for studenten. Når studentene betrakter sine veiledere som rollemodeller, blir det en stilltiende aksept på at de deltar i en enveis læringsprosess der praksislærerne får stor påvirkning på studentenes forståelse av praksis. Studentene kan komme $i$ en lojalitetskonflikt når de samtidig blir oppfordret av sin lærerutdanner på høgskolen til å utfordre det bestående og tradisjonelle (Douglas, 2012). Studentene forteller mer generelt at det de veiledes til, er ganske forskjellig. Samtidig innbyr noen utsagn fra studentene til en annen måte å forstå veiledning på. I noen grad utfordrer den skillet mellom utviklende veiledning, som i handlings- og refleksjonsmodellen, og klar veiledning, som i supervisjonstradisjonen (Lejonberg 2016; Gordan 1992). Nilssen viser til en overgripende tilnærming til veiledning når hun beskriver en praksislærer som han/hun $i$ undervisningen viser og modellerer samtidig, og som han/hun $i$ veiledningssamtaler med studentene drøfter og reflekterer over $\mathrm{i}$ etterkant av undervisningen. Praksislæreren begrunner denne doble tilnærmingen med at studentene trenger assistanse til å forstå og bruke didaktiske begrep fordi de ikke har nok erfaring og teori som grunnlag for å undervise og virke som pedagoger. Således tar praksislæreren utgangspunkt i sin egen praktiske yrkesteori og ikke i studentenes (Nilssen, 2010).

Vårt poeng er ikke at den ene formen for veiledning er å foretrekke framfor den andre. Den dyktige praksislærer har som grunnlag for sin virksomhet, høy grad av kontekstuell og kulturell kompetanse. I tillegg til å ha skaffet seg en generell veilederkompetanse har han/hun en god relasjon til sin veisøker Han/hun velger derfor en form for veiledning som passer til situasjonen. En måte praksisłærerne kan skaffe seg den nødvendige kulturelle og kontekstuelle kompetanse på, er å bli kjent med, forstå og virke i den sfære studenten befinner seg i deler av studieåret, nemlig på campus. For å bli tilført dette bør praksislærerne inviteres og motiveres til å delta i undervisningsaktiviteter på campus (Sträng, 2016). Samtidig er det viktig at studentene utvikler kunnskap om den skolekulturen de møter i praksis. En måte å få dette til på uttrykkes av en praksislærer slik: «Jeg vektla i min veiledning å inkludere kandidaten mest mulig på ting i lærerens hverdag ... jeg inviterte henne med til lunsj og de møtene som var aktuelle for henne». Viktigheten av en slik inkluderende holdning og forståelse av veilederrollen, understrekes også $i$ sentral forskning på partnerskap. Den vektlegger at praksislærerne sosialiserer studentene inn i lærerprofesjonen, guider dem gjennom alle skolens praktiske gjøremål ved å introdusere dem til praksis, og lærer dem å bevege seg i skolens kontekst (Clarke et al., 2013). 


\section{Praksislærerens mangelfulle veiledningskompetanse og tilretteleggingssvikt}

Flere praksislærere uttalte at de manglet de nødvendige ferdigheter for å kunne veilede sine studenter på en læringsfremmende måte: «Jeg savner veiledning eller et kurs om hvordan være veileder». De fleste praksislærerne ved begge praksisskolene manglet formell veilederutdanning. Imidlertid hadde et overveiende flertall av dem relativt mye og lang erfaring med å veilede studenter i praksis. Det er et spørsmål om lang erfaring kan kompensere for kunnskap og kompetanse tilegnet gjennom en veilederutdanning. Flere studenter rapporterte at de mottok vage tilbakemeldinger, og at enkelte praksislærere virket usikre. Det å få svar som «hm» eller «dette gikk bra det», er ganske upresist. Noen studenter mottok veiledning "over en kopp kaffe» eller $i$ andre uformelle sammenhenger: «Vi satte ikke av fast tid til samtale og drakk kaffe og snakket sammen, og det fungerte bra de første ukene. Deretter ble det lite med veiledning. Jeg tenker at praksislærer kanskje ble usikker på hva mer han skulle bidra med i samtalene». I følge lærerutdanningens studieplan og plan for praksisopplæringen er intensjonen at studentene skal innlemmes i et profesjonsfellesskap. Der får de bl.a. støtte i planlegging og gjennomføring av undervisning, i å gi læringsfremmende tilbakemeldinger til elever, til å vurdere elevenes læring, og til å vise omsorg for elevene (Høgskolen i Østfold, 2014a og b). Vårt materiale tyder på at enkelte studenter i noen grad blir overlatt til seg selv uten nevneverdig st $\varnothing$ tte fra praksislærer. Funn fra annen forskning indikerer at dette skjer fordi studentene møter praksislærere med lite veilederutdanning og manglende kompetanse. Dette kan føre til at studentene utvikler en profesjonsforståelse som ikke tar inn over seg kompleksiteten i lærerrollen (Chambers \& Armour, 2012). En metastudie viser at veiledningssamtalene tenderte mot å bli mer konstaterende enn undersøkende i sin form, at praksislærernes vurderinger ofte var generelle og av summativ karakter, og i liten grad la vekt på formative aspekter. Studien kobler dette til at praksislærerne i mange av de omtalte forskningsprosjekter var usikre og manglet kompetanse til å evaluere studenter (Clarke et al., 2013). Andre praksislærere inviterte imidlertid studenter inn i reflekterende og konstruktive samtaler. En student skriver om sin praksislærer: "Jeg har hatt en svært god relasjon til min praksislærer. I tillegg til god personlig kjemi, har jeg opplevd stor grad av tillit og autonomi, samt konkret og konstruktiv tilbakemelding». En annen uttaler: "Jeg utviklet gode samarbeidsforhold til begge praksislærerne, og lærte mye av å diskutere og tenke over faginnhold og undervisning med dem». Praksisopplæring blir således ikke bare en plass der studenten blir ført inn i en etablert praksis, men også en plass der studenten sammen med sin praksislærer kan drøfte hvordan en kan dele ulike kunnskaper og erfaringer i en felles læreprosess. Samarbeid mellom studenter og praksislærer som organiseres slik at de kan dele tanker og erfaringer om samme undervisningsspørsmål, gir grunnlag for utvikling av felles reflektert praksis (Hagger \& Maclntyre, 2000). Flere praksislærerutsagn viser at tilstedeværelse i studentenes undervisning med derpå tilknyttede veiledningssamtaler også har bidratt til vekst, utvikling og læring for dem som lærere: «Jeg synes også det har vært fint å høre om nye teorier og teoretikere som studentene leser om - på den måten synes jeg det blir en hel del gjensidig læring»; og "Jeg ser det som viktig hele tiden å lære noe nytt og å være åpen for endring. Veilederrollen gir meg en unik mulighet til dette - til faktisk å reflektere over egen praksis i møte med PPU-studentene». Clarke et al. (2013) finner at praksislærere bl.a. øker sin profesjonskunnskap i interaksjonen med studenter fra lærerutdanninger.

\section{Felles læring i det tredje rom}

I en tidlig fase i forskningsprosjektet uttrykker en praksislærer seg slik om behovet for kompetanse og felles refleksjon: «Skal vi som praksisskole utvikle god kompetanse på veilederrollen, kan vi trenge felles refleksjon på hvilke forventninger dere som høgskole har til oss som veiledere». Denne praksislæreren etterlyser kollektive læreprosesser som et samspill mellom aktørene fra de to systemene praksisskole og lærerutdanning. En slik tilnærming der studenter, praksislærere og lærerutdannere med utgangspunkt i sin individuelle læring og erfaring, samhandler og samarbeider, kan utvikles til en meningsfull kollektiv læringsprosess (Tuomi-Gröhn, 2007). Samarbeidet mellom praksisskole og lærerutdanning vil inkludere 
læring gjennom samspill på tvers av system der aktørene kan gi felles mening til og utvikle nye teoretiske begrep og redskaper for praktisk utøving av lærerprofesjonen.

Tidlig i partnerskapet med våre praksisskoler inviterte vi til caseinspirerte og dialogbaserte læringsøkter om forhold knyttet til veiledning av studenter. Fra studieåret 2016/2017 er også studentene inkludert i disse samlingene slik at oppfatninger, læring og forståelse blir felles eie for de sentrale deltakere i praksisopplæringen. Breault \& Breault (2010) framhever kompetanse, kapasitet og gode relasjoner mellom deltakerne som suksesskriterier for gode partnerskap mellom skoler og lærerutdanningsinstitusjoner. Mye tyder på at man kan utvikle et vellykket partnerskap dersom partene kan enes om å samarbeide om felles læringsobjekter. Et slikt læringsobjekt kan være å designe en veilederutdanning som er erfarings- og konteksttilpasset. Samarbeidet kan da dreie seg om å utvikle en felles oppfatning av hvordan denne utdanningen kan forbedres og utvikles, og at partnerskapet blir organisert knyttet til dette felles læringsobjektet. Dette rimer godt med «tredjeroms-tenkning» (Zeichner, 2010), hvor "det tredje rom» er et mulighetsrom hvor partene styrker hverandre gjensidig gjennom aktivitetene de utøver (Bier et al., 2012). Lærerutdannere på PPU ved angjeldende høgskole har initiert en slik praksisorientert veilederutdanning.

\section{Trepartsamtalen}

Forskning på trepartsamtalen som foregår i det tredje rom, peker på spenninger som kan oppstå mellom aktører. Det medfører at studenter kan havne i en lojalitetskonflikt, hvor de tvinges til å velge side (Parylo, 2013). I vårt materiale finner vi i liten grad spor av opplevelse av konflikt eller lojalitetsproblemer. Vi har derfor så langt ikke problematisert relasjonene i trepartsamtalen. Vårt materiale tyder derimot på at samtalen bidrar til at studentene på en deltakerorientert og inkluderende måte føres inn i lærerprofesjonen.

Trepartsamtalen betraktes som en særdeles viktig del av studentens praksis-opplæring/-veiledning. I denne samtalen møtes student, praksislærer og lærerutdanner for å drøfte sentrale og observerte elementer i studentens undervisning. Samtidig skal samtalen også skal gi rom for å ta opp andre viktige forhold knyttet til studentens profesjonsut øvelse. Studentene gir gjennomgående uttrykk for at de var fornøyde med trekantsamtalene. De var spesielt opptatt av at lærerutdanner var tilstede og deltakende. En student skriver: «Jeg synes det var svært nyttig at lærerutdanner var tilstede både i min undervisning og i samtalen vi hadde i etterkant - det er jeg svært fornøyd med. Det gir praksislærer og lærerutdanner mulighet til å skaffe seg et så helhetlig bilde som mulig, samt at samtalen blir mer reell og er tuftet på praksislærers og lærerutdanners egne inntrykk». Trepartsamtalen utgjør i tillegg en mulighet for å knytte sterkere bånd mellom praksisskoler og lærerutdanningsinstitusjon. Flere av praksisskolenes lærere har tatt initiativ til å skaffe seg formell veilederutdanning gjennom studiet «Pedagogisk veiledning» (Høgskolen i Østfold, 2014a). Da tar de studiet samtidig som de er praksislærere for studenter fra PPU fra samme institusjon. Denne dobbeltrollen gir rom for medvirkning i utviklingen av veilederutdanningen og for å bruke trepartsamtalen i praksisopplæringen som et konkret virkemiddel for $\varnothing$ kt grad av koherens. Det at praksislærere og studenter utdannes ved samme lærerutdanning til dels av de samme lærerutdannere, åpner samtidig opp for større indre sammenheng i en lærerutdanning som fra flere hold kritiseres for å være fragmentert og preget av «vedvarende tautrekking» (Kunnskapsdepartementet, 2017).

\section{Koherensillojalitet i veiledningen}

Flere studenter gir uttrykk for misnøye med gruppeveiledning gitt av en praksislærer ved en av praksisskolene. De oppfattet denne som ensrettet og monologisk. En student skriver: «Spesielt finner jeg det merkelig at NN flere ganger på fellesmøter åpent kritiserte fremgangsmåtene til lærerutdannerne på campus. Spesielt gjaldt dette hvordan man skal legge opp timer, og hvordan disse skal planlegges og gjennomføres». I utgangpunktet kan dette fenomenet ses på som mangel på sammenheng og som konfliktskapende oppfatninger mellom lærerutdanning og praksisfelt. Sett $i$ et annet perspektiv, der koherens ikke framstår som noe uniformt, men mer som ulike syn på en felles sak og et eksempel på rik 
variasjon over et felles tema, kan dette være en invitasjon til å drøfte med vedkommende hvordan undervisning skal planlegges og gjennomføres (Schollaertes, 2011).

I tillegg vil vi hevde at praksislæreren her vektlegger en måte å veilede på som er preget av kontroll, konstatering og mangel på undring. Slike mangler vitner om en praksislærer som er ekspert, og som peker ut den retning hun vil at kandidatene skal utvikle seg i. Bjerkholt $(2017$, s. 31) løfter opp et lignende eksempel når hun i en studie avdekker praksislærere som ifølge en veisøker «... har hatt problemer med å holde seg til det saklige og objektive, så jeg følte det var mer informasjon om hvordan konkret man må gjøre ting for å få en bra karakter, enn veiledning.»

\section{Praksislæreres verdivalg}

Praksislærerne kan være ulikt motivert for, og ha forskjellige begrunnelser for å påta seg et frivillig ekstraarbeid som veiledningsoppgavene representerer. Flere praksislærere på begge praksisskolene plasserte veilederoppgaven inn i et større perspektiv. De hadde en profesjonsbevissthet preget av ansvar. En praksislærer omtalte sin rolle slik: «Grunnen til at jeg sa ja til å være praksislærer, er både av egeninteresse og av et samfunnsansvar vi har som lektorer i den videregående skole - og ikke minst så kan jeg tilføre studentene noe av det jeg synes er viktig i lærerrollen: gi av erfaring fra min praksishverdag». Også annen forskning på partnerskap viser at praksislærere gjør slike verdivalg. Le Cornu (2012) viser til praksislærere som var opptatt av at studenter skulle settes inn i lærerrollen, og at praksislærerne følte en moralsk forpliktelse overfor framtidige lærere.

\section{Tid og ressurser i veiledningen}

Tid oppleves som en kritisk faktor av både studenter og praksislærere. Beskrivelser av tid som rammefaktor går som en rød tråd gjennom flere av tekstene. "Nok tid» synes å bidra til læring, trivsel og en følelse av kontinuitet og sammenheng. En student gir stemme til det som flere studenter rapporterer: «Siden jeg stort sett befant meg i klasserommet eller på personalrommet, hadde jeg hele tiden praksislærerne mine tilgjengelige». En annen student skriver; "Jeg hadde de samme veilederne før og etter jul. Det så jeg som en fordel, fordi jeg visste hva de forventet av meg, og jeg fikk en god relasjon til dem». Utsagnene vitner om at nok tid sammen bidrar til kvalitet på forholdet mellom praksislærer, og fører studenten inn i utviklende læreprosesser. Dersom kollegialitet og støttestrukturer blir svak og disponibel tid til samvær liten, svekkes kvaliteten på relasjonene og sannsynligheten for at «partnerskapet» mislykkes øker (Breault \& Breault, 2010). En praksislærer opplever mangel på tid som virker demotiverende: «Jeg må være ærlig og si at når jeg tar på meg den arbeidsmengde med den tid det tar, og ikke minst stress sammen med misfornøyde elever, er jeg svært lite lysten på å gjøre dette igjen». Denne type tverrinstitusjonelt arbeid forutsetter også økonomiske ressurser, og arbeidet bør ikke komme på toppen av den store arbeidsbyrden praksislærere og lærerutdannere har (Petersen \& Treagust, 2014). Partnerskap er mer ressurskrevende enn mer tradisjonell lærerutdanning, noe også vår studie dokumenterer.

\section{Konklusjoner og visjoner}

Hvilke svar har vi fått på vårt forsknings-spørsmål: Hvilke bidrag kan veiledning gi i lærerstudenters praksisperioder? Oppsummert viser vår studie at:

- Praksislærere som fungerer som gode veiledere, har utviklet kontekstorienterte tilnærminger til veiledning av lærerstudenter

- Praksislæreres veiledningsfaglige kompetanse er avgjørende med hensyn til om lærerstudentene ser og opplever kontinuitet og sammenheng i lærerutdanningen. I tillegg er det av betydning at veiledningsrelasjonene og betingelsene for disse er gode

- Både lærerstudenter og praksislærere mener at de lærer noe nytt om sin egen profesjon i samhandling med andre, og at kollektiv læring skjer på tvers av systemer

- Lærerstudentene setter ikke pris på veiledning som er ensrettet, kontrollfiksert og konstaterende 
- Noen praksislærere oppfatter at de som utdannede og erfarne pedagoger har et selvsagt ansvar for å føre sine studenter inn i lærerrollen

- Lærerstudentene gir gjennomgående uttrykk for at trepartsamtalene er læringsfremmende, spesielt setter de pris på at lærerutdanner deltar

- Både praksislærere og lærerstudenter opplever at tid og ressurser er avgjørende suksessfaktorer i studentenes praksisperioder

\section{Grensekryssende studenter hjelpes av grensemeklende lærerutdannere}

På praksisskolene møter studentene en ny virkelighet som de har oppfatninger om og forventninger til, og som de kan oppleve som både spennende, utfordrende og skremmende. Å komme fra de relativt trygge og forutsigbare rammene som en lærerutdanningsinstitusjon er for de fleste studenter, til det å krysse grensen mot praksisskole, kan oppleves som krevende. Waitoller og Kozleski (2013) peker på at det kan oppstå spenninger i relasjoner mellom partene, bl.a. på grunn av makt, privilegier, oppfatninger og holdninger til hva slags kompetanse som har verdi, og at under slike forhold trengs grensemeklere. Vår studie indikerer at lærerutdannerne som er tilstede på praksisskolene, både i trepartsamtaler og ellers, oppleves av studentene som slike støttende grensemeklere. De fikser det som må fikses, er tilgjengelige og kan trå til når det er nødvendig. En av lærerstudentene skriver: «Har det vært problemer, så har lærerutdanner alltid vært tilgjengelig og vært opptatt av at vi studenter skal trives. Det har vært en stor trygghet å vite at det er noen fra høgskolen som er på studentens side». Et fruktbart perspektiv på partnerskap mellom praksisskoler og lærerutdanningen er å betrakte og forstå denne samhandlingen som grenseaktiviteter. Grenser kan skille, men kan også innebære overlapping i form av kontinuitet og sammenfallende syn. Grensekrysserne i partnerskap er de som beveger seg inn i det ukjente. De forhandler om begrepsbruk og om hvordan redskaper skal benyttes. Grensekrysserne blir da meklere som gjennom relasjonelle handlinger kan engasjere seg i å utvikle læreres profesjonsfaglige kunnskap (Edwards, 2007). Lærerutdannernes rolle som grensemeklere ønsker vi å utforske og utvikle videre. I tillegg til å legge vekt på den betydning lærerutdannerne har, er også studentene opptatt av forholdet til medstudenter. De setter stor pris på samvær og samarbeid med de andre studentene på praksisskolen, og den st $\varnothing t t e$ andre studenter kan gi i vanskelige perioder. En student skriver: «En av de mest lærerike faktorene med praksisperioden, i tillegg til praksis, er samtalene med medstudenter. Å lære av hverandre, gi tilbakemeldinger og tips til undervisningsopplegg har vært noe av det mest lærerike med hele praksisperioden». Lærerutdanneres og medstudenters betydning vil vi gi økt oppmerksomhet i vårt videre arbeid med å utvikle det tredje rom.

\section{Litteratur}

Berg, G. (2003). Att förstå skolan. En teori om skolan som institution och skolor som institutioner. Lund: Studentlitteratur.

Bier, M. L., Horn, I., Campbell, S. S., Kazemi, E., Hintz, A., Kelley-Petersen, M., Stevens, R., Saxena, A. \& Peck, C. (2012). Designs for Simultaneous Renewal in University-Public School Partnerships: Hitting the" Sweet Spot". Teacher Education Quarterly, 39(3), 127-141.

Bjerkholt, E. (2017). Profesjonsveiledning. Fra praktisk virksomhet til teoretisk felt. Oslo: Cappelen Damm akademisk.

Breault, D. A. \& Breault, R. (2010). Partnerships for preparing leaders: what can we learn from PDS research? International Journal of Leadership in Education, 13(4), 437-454.

Chambers, F. \& Armour, K. (2012). School-university partnerships and physical education teacher education student learning: A fruitful division of labour? European Physical Education Review 18(2), 159-181.

Clarke, A., Triggs, V. \& Nielsen, W. (2013). Cooperating Teacher Participation in Teacher Education. A Review of the Literature. Review of Educational Research, 84(2), 163-202. 
Darling-Hammond. L., (2014). Strengthening Clinical Preparation: The Holy Grail of Teacher Education. Peabody Journal of Education, 89(4), 547-561. https://doi.org/10.1080/0161956X.2014.939009

Douglas, A. S. (2012). Creating expansive learning opportunities in schools: the role of school leaders in initial teacher education partnerships. European Journal of Teacher Education, 35(1), 3-15.

Dysthe, O. (1993). Ord på nye spor: innføring i prosessorientert skrivepedagogikk (2. utg.). Oslo: Samlaget.

Edwards, A. (2007). Relational Agency in Professional Practice: A CHAT Analysis. Actio: An International Journal of Human Activity Theory, 1, 1-17.

Ellis, C. \& Bochner, A. P. (2000). Autoethnography, personal narrative, reflexity: Researcher as subject. I N. K. Denzin \& Y. S. Lincoln (Red.), Handbook of Qualitative Research (s. 733-768). London: Sage.

Fangen, K. (2009). Kvalitativ metode. Oslo: Forskningsetiske komiteer.

Giorgi, A. P. (1997). The Theory, Practice, and Evaluation of the Phenomenological Method as a Qualitative Research Procedure. Journal of Phenomenological Psychology, 28(2), 235-260.

Gordan, K. (1992). Psykoterapihandledning inom utbildning, i kliniskt arbete och på institution. Stockholm: Natur och Kultur.

Grimen, H. (2008). Profesjon og kunnskap. I A. Molander \& L. I. Terum (Red.), Profesjonsstudier (s. 7186). Oslo: Universitetsforlaget.

Hagger, H. \& Mclntyre, D. (2000). What can research tell us about teacher education? Oxford Review of Education, 26(3-4), 483-494.

Halvorsen, K. V. (2014). Utvikling av partnerskap i en femårig lektorutdanning - sett fra et økologisk perspektiv. Norsk pedagogisk tidsskrift, 98(01), 14-25.

Hammerness, K. (2006). From coherence in Theory to Coherence in Practice. Teachers College Record, 108(7), 1241-1265.

Hammerness, K., Darling-Hammond, L. \& Shulman, L. (2002). Toward expert thinking: How curriculum case writing prompts the development of theory-based professional knowledge in student teachers. Teaching Education, 13(2), 219-243.

Heggen, K. \& Smedby J. C. (2012). Gir mest mulig samanheng også den beste profesjonsutdanninga? Norsk pedagogisk tidsskrift, 96(1), 4-14.

Heggen, K. \& Raaen, F. D. (2014). Koherens i lærarutdanninga. Norsk pedagogisk tidsskrift, 98(01), 3-13.

Helleve, I. \& Langøren, K. (2018). Veilederutdanning. I K. Smith \& M. Ulvik (Red.), Veiledning av nye lærere (187-204). Oslo: Universitetsforlaget

$\mathrm{H} \varnothing$ gskolen i $\emptyset$ stfold $(\mathrm{Hi} \varnothing)$. (2014a). Studieplan for Pedagogisk veiledning. Hentet fra https://www.hiof.no/studier/emner/lu/2014/var/luvpo113.html

Høgskolen i $\emptyset$ stfold (Hi $\varnothing$ ). (2014b). Studieplan for Praktisk-pedagogisk utdanning heltid. Hentet fra https://www.hiof.no/studier/emner/lu/2014/host/lphped12.html

Kunnskapsdepartementet. (2008). Læreren Rollen og utdanningen (St.meld. nr. 11 (2008-2009)). Hentet fra https://www.regjeringen.no/no/dokumenter/stmeld-nr-11-2008-2009-/id544920/

Kunnskapsdepartementet. (2017). Lærerutdanning 2025. Nasjonal strategi for kvalitet og samarbeid $i$ lærerutdanningene. Hentet fra https://www.regjeringen.no/contentassets/d0c1da83bce94e2da21d5f631bbae817/kd nasjonalstrategi-for-larerutdanningene nett.pdf

Lauvås, P. \& Handal, G. (2014). Veiledning og praktisk yrkesteori. Oslo: Cappelen Damm Akademisk. Le Cornu, R. J. (2010). School co-ordinators: Leaders of learning in professional experience. Australian Journal of Teacher Education, 37(3), 17-33. 
Lejonberg, E. (2016). Hva kan bidra til god veiledning? En problematisering basert på veilederes og veisøkeres perspektiver på veiledning av begynnende lærere (Doktoravhandling). Universitetet i Oslo.

Lid, S. E. (2013). PPUs relevans for undervisning i skolen. En kartlegging av studenters og nyutdannede læreres oppfatninger (NOKUT-rapport 2013/2). Oslo: NOKUT.

McDonald, M., Tyson, K., Brayko, K., Bowman, M., Delport, J. \& Shimomura, F. (2011). Innovation and Impact in Teacher Education: Community-Based Organizations as Field Placements for Preservice Teachers. Teachers College Record, 113(8), 1668-1700.

Munhall, P.L. (2007). Nursing research. A qualitative perspective. Boston: Jones and Bartlett Publishers.

Nilssen, V. L. (2007). Seeing the kids - seeing the student teachers, dealing with two arenas the whole way. A case study of a cooperating teacher mentoring first-year student teachers' mathematics teaching (Doktoravhandling). Trondheim: NTNU.

Parylo, O. (2013). Collaborative Principal Preparation Programs: A Systematic Review and Synthesis of Qualitative Research. International Journal of Educational Leadership Preparation, 8(2), 177-191.

Petersen, J. E. \& Treagust, D. F. (2014). School and university partnerships: The role of teacher education institutions and primary schools in the development of preservice teachers' science teaching efficacy. Australian Journal of Teacher Education, 39(9), 153-167.

Pålshaugen, $\varnothing$. (1994). A Norwegian Programme of Action Research for participative Democracy. Oslo: Arbeidsforskningsinstituttet.

Raaen, F. D. (2017). Organisering og utbytte av praksis-opplæringen. I S. Mausethagen \& I. Smeby (Red.), Kvalifisering til profesjonell yrkesutøvelse (s. 106-116). Oslo: Universitetsforlaget.

Schollaertes, R. (2011). Continuing professional development for the 21st century: setting the scene for teacher induction in a new era. I P. Picard \& L. Ria (Red.), Beginning teachers: a challenge for educational systems - CIDREE Yearbook 2011 (s. 9-28). Lyon, France: ENS de Lyon, Institut francais de L'Education.

Segaard, S. B. (2007). Refleksivitet i følgeforskning - Strategi, roller og utfordringer. Paper presentert på Statsvitenskapelig Fagkonferanse, Trondheim.

Sträng, D. R. (2016). Handledning och kulturkompetens. I M. Jensen, T. Karlsen \& G. Luthen (Red.), Veiledning og oppdagelse (s. 203-216). Oslo: Gyldendal Akademisk.

Tatto, M. T. (1996). Examining Values and Beliefs about Teaching Diverse Students: Understanding the challenges for Teacher Education. Educational Evaluation and Policy Analysis, 18(2), 155-180.

Tuomi-Gröhn, T. (2007). Developmental Transfer as a Goal of Collaboration between School and Work: A Case Study in the Training of Daycare Interns. Actio: An International Journal of Human Activity Theory, 1, 41-62.

Tranøy, K.E. (1986). Vitenskap - samfunnsmakt og livsform. Oslo: Universitetsforlaget.

Waitoller, F. R. \& Kozleski, E. B. (2013). Working in boundary practices: Identity development and learning in partnerships for inclusive education. Teaching and Teacher Education, 31, 35-45.

Walford, G. (2004). Finding the limits: autoethnography and being an Oxford University Proctor. Quality Research, 4(3), 403-417.

Weber, M. (1956). Soziologie, weltgeschichtliche Analysen, Politik. Stuttgart: Alfred Kröner.

Zeichner, K. (2010). Rethinking the Connections Between Campus Courses and Field Experiences in College- and University-Based Teacher Education. Journal of Teacher Education, 61(1-2), 89-99. 